\title{
Synchronous Primary Endometrial Carcinoma and Metastatic Malignant Melanoma in an Ovarian Cystic Teratoma
}

\section{Eş Zamanlı Primer Endometrial Karsinom ve Ovaryan Kistik Teratomdan Gelişen Malign Melanom}

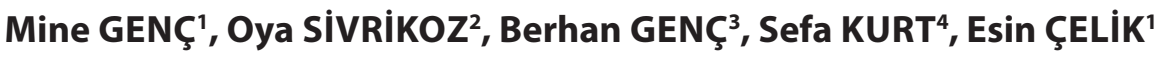 \\ Department of ${ }^{1}$ Obstetric \& Gynecology, ${ }^{2}$ Pathology, and ${ }^{3}$ Radiology, Şifa University, Faculty of Medicine, IZMIR, TURKEY \\ ${ }^{4}$ Department of Obstetric \& Gynecology, Aegean Maternity and Women's Health Hospital, IZMIR, TURKEY
}

\begin{abstract}
Malignant transformation of a benign cystic teratoma of the ovary is only rarely seen. A review of the English literature revealed no reports of a malignant melanoma developing from concurrent primary endometrial carcinoma and ovarian cystic teratoma. We report herein a 54-year-old nulliparous woman who underwent total abdominal hysterectomy and bilateral salpingo-oophorectomy for a pelvic mass and was diagnosed by histopathological examination to have a malignant melanoma developing from concurrent primary endometrial carcinoma and ovarian cystic teratoma. No foci of primary malignant melanoma except for the ovary were found upon clinical examination. The patient received postoperative interferon alpha $2 \mathrm{~B}$ and radiotherapy. She was still asymptomatic at 12 months of follow-up.
\end{abstract}

Key Words: Melanoma, Ovary, Teratoma, Endometrial neoplasms
ÖZ

Overin benign kistik teratomunun malign transformasyonu oldukça nadirdir. İngiliz literatürünün gözden geçirilmesinde eş zamanlı primer endometrial karsinom ve overde kistik teratomda gelişen malign melanom olgusuna rastlanmamıștır. Burada 54 yaşında doğum yapmamış, total abdominal histerektomi ve bilateral salpingo ooferektomi sonrasinda primer endometrial karsinom ve ovaryan kistik teratomda gelişen malign melanom tanısı alan bir olgu sunuyoruz. Klinik muayenede over dışında melanom saptanmadi. Hasta operasyon sonrası interferon-alpha (IFN- $\alpha$ ) $2 \mathrm{~B}$ ve radyoterapi tedavisi aldi. Tedavi sonrası 12 ay boyunca izlenen hasta asemptomatiktir.

Anahtar Sözcükler: Melanom, Over, Teratom, Endometrial tümörler

\section{INTRODUCTION}

Malignant transformation of a mature teratoma is quite rare. The literature incidence of such an event ranges between 0.8 to $5 \%$ (1). Being at the postmenopausal period at the time of diagnosis increases the risk of malignant transformation. Squamous cell transformation accounts for $90-97 \%$ of all malignant transformations of mature teratomas. Other tumor types include fibrosarcoma, leiomyosarcoma, osteosarcoma, basal cell carcinoma, and melanoma (2-4). Primary ovarian malignant melanoma was first reported in 1901 (5). A total of 37 cases have been reported so far in the English literature (6-12).

This case is the first and only case in which a primary malignant melanoma developed from a mature teratoma of ovary while there was a concurrent primary endometrial carcinoma in uterus. Postsurgical histopathological

(Turk Patoloji Derg 2015, 31:215-218)

Received : 17.11.2011 Accepted : 12.01.2012 examinations reveal concurrent primary ovarian and primary endometrial carcinoma at a rate of 5-15\%, while the same rate climbs up to $30-40 \%$ in postmortem examinations (13-14).

\section{CASE REPORT}

A 54-year-old nulliparous woman presented with pain and swelling in the lower abdomen that had lasted for 5 months without any additional symptoms. During a pelvic examination, a non-tender cystic mass was felt anterior to the uterus. CA125 was markedly elevated at $278 \mathrm{U} / \mathrm{mL}$. Ultrasound and computed tomography scans identified a multilobular right ovarian cyst measuring $18 \mathrm{~cm}$ and $14 \mathrm{~cm}$ (Figure 1).

The pelvic mass was removed completely. Histology of the frozen sections indicated the presence of a malignancy and a

Correspondence: Mine GENC

Şifa Üniversitesi, Tıp Fakültesi, Kadın Doğum Anabilim Dalı,

IZMİR, TURKEY

E-mail: doktorminegenc@hotmail.com Phone: +90 2324460880 


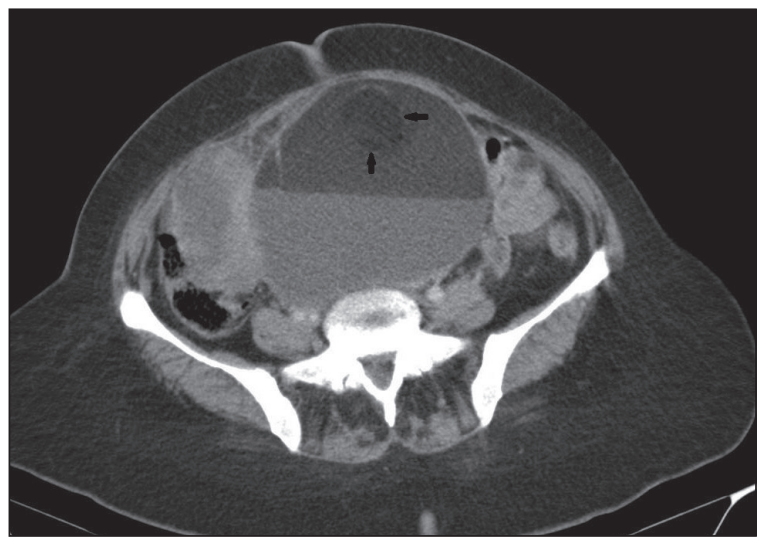

Figure 1: Mature cystic tumor in a 56-year-old woman. Contrastenhanced axial CT scan of the midportion of the mass shows a typical teratoma that contains fat (black arrows). Wall of the cysts and septa showed apparently strong contrast enhancement on CT.



Figure 2: Gross appearance of the primary ovarian malignant melanoma with a cystic teratomatous portion.


Figure 3: Photomicrograph shows pathological features of the malignant melanoma arising in the mature cystic ovarian teratoma.

A) Cyst wall lined with squamous epithelium, a mature teratoma and malignant melanoma is observed in the upper left side (H\&E $\mathrm{x} 40$ ).

B) Melanoma cells have large, hyperchromatic nuclei with irregularly clumped nuclear chromatin, and contain cytoplasmic melanin pigment (H\&E x200). C) S-100 positive staining of the tumor cells (S-100 x100). D) HMB-45 positive staining of the tumor cells (HMB$45 \times 100)$. 


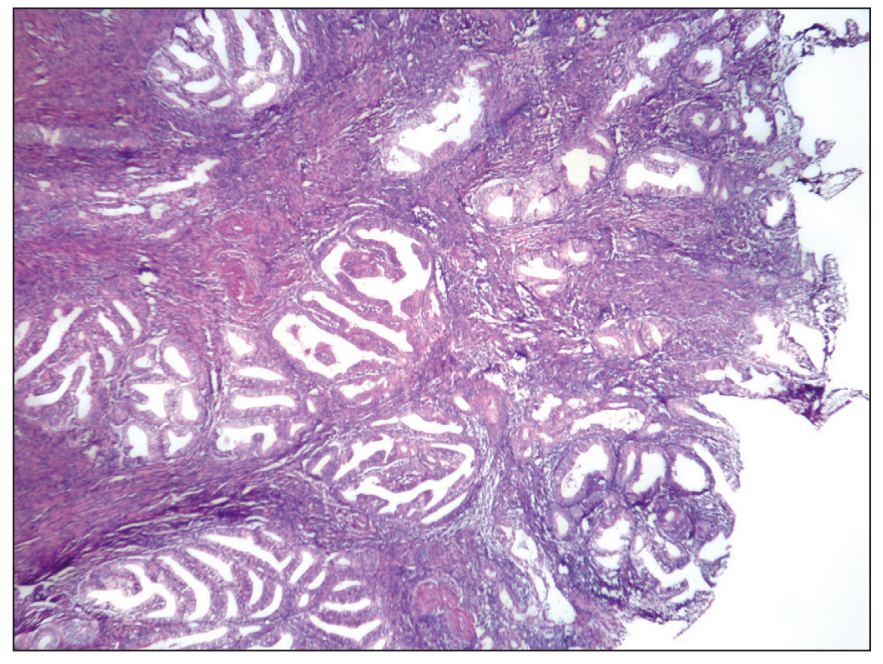

Figure 4: Photomicrograph shows well -differentiated endometrioid adenocarcinoma (H\&E x100).

total abdominal hysterectomy, left salpingo-oophorectomy, pelvic-para-aortic lymphadenectomy, appendectomy and omentectomy was performed simultaneously. The right cystic ovarian mass that consisted of numerous solid brown areas and had a maximum diameter of $3.5 \mathrm{~cm}$ and was 14 $\mathrm{cm}$ in diameter was sent to the pathology laboratory (Figure 2).

Microscopic examination showed squamous epithelium, sebaceous glands, and hair follicles consistent with a mature cystic teratoma. In one area, atypical cells with melanin pigment deposition were seen underlying the epithelium. These cells displayed nuclear pleomorphism and increased mitotic activity. The tumor cells were positive for S100, Melan A, HMB45 and vimentin. The cells were negative for pancytokeratin and inhibin. The findings described above were most consistent with a diagnosis of malignant melanoma arising in a mature cystic teratoma (Figure 3AD).

Paraaortic lymph nodes displayed evidence of malignant melanoma metastasis. The left ovary, omentum and appendix were free of malignant melanoma involvement. In the tissue removed by the hysterectomy, a 'welldifferentiated endometrioid carcinoma' that involved the inner half of the endometrial wall was found (Figure 4).

Postoperatively, interferon 2B and radiation therapy (RT) was administered. She received IFN- $\alpha$ 2B 5.000.000 U three days per week for two months. In addition, paraaortic and pelvic RT (4500 cGy) was administered for 25 days.

\section{DISCUSSION}

The rate of concurrent endometrial and primary ovarian cancer is $5-15 \%$, while it is $30-40 \%$ in postmortem examinations (13-14). The most common tumor of ovary is epithelial ovarian cancer. However, the most common tumor concurrent with endometrium cancer is granulosa cell ovarian tumor (15). Ovarian sex cord tumors and steroid cell tumors have a very similar structure to ovarian melanoma. But sex cord stromal cell tumors and steroid cell tumors are S-100 and melan-A negative (16). Malignant melanoma tumor cells are positive for S-100 and Melan-A. However, we were unable to find a report of synchronous primary endometrial carcinoma and primary malignant melanoma in an ovarian cystic teratoma in the literature.

Concurrence of ovarian and endometrial malignancies may be classified in 3 groups: (a) metastasis of a primary endometrial carcinoma to ovary, (b) metastasis of a primary ovarian cancer to endometrium, and (c) concurrent primary ovarian and endometrial carcinomas. Clinical and histopathological characteristics of this patient suggested that the 2 tumors were separate, distinct malignancies and neither of two was a metastasis of the other. It is evident that the primary focus of the melanoma was the ovarian teratoma because of absence of a previous history of melanoma, absence of another melanoma focus on physical examination, and presence of melanoma solely in ovarian tissue. Nevertheless, there was no relationship between malignant ovarian melanoma and the concurrent welldifferentiated endometrium cancer. We therefore considered both tumors as occurring together by coincidence.

Although, malignant melanoma primarily originating from ovary is very rare, postmortem examinations have revealed that $18 \%$ of extra-ovarian malignant melanoma cases have also tumor in ovary (1). A comprehensive literature review revealed 37 cases of malignant melanoma originating from ovary. The first case dates back to 1901 (6-12). Cronge and Wooduff accepted absence of an extra-ovarian focus of malignant melanoma, presence of a focus of malignant melanoma in the same ovary harboring teratoma, and showing melanocyte junctional activity as diagnostic criteria for a primary ovarian malignant melanoma (17).

Primary ovarian melanoma is a tumor with a considerably malignant course and already has metastases at the time of diagnosis (18). Treatment for epithelial malignancies originating from ovarian dermoid cystsis similar to that given for other ovarian malignancies, although optimal treatment has yet to be established (19). Malignant melanoma has a substantially poorer prognosis compared to malignancies originating from superficial epithelium or dermoid cyst of ovary (20). Treatment of primary melanoma consists of surgical excision including regional lymph nodes. Other additional therapies include radiation, chemotherapy and 
administration of chemoimmunotherapy. Alfa-interferon and interleukin 2 (immunotherapy) are promising new treatments for metastatic melanoma (21).

Postoperatively, our patient received combination IFN- $\alpha 2 B$ and radiotherapy. Subsequently, she remained asymptomatic for 12 months. We have not detected serious side effect during the treatment. A combination of surgical debulking and immunotherapy may be of significant benefit in this rare disease.

\section{REFERENCES}

1. Nogales FF. Germ cell tumours of the ovary. In: Fox H, Wells $\mathrm{M}$, editors. Haines and Taylor obstetrical and gynaecological pathology. New York: Churchill Livingstone; 1995:847-96.

2. Stamp GW, McConnell EM. Malignancy arising in cystic ovarian teratomas. A report of 24 cases. Br J Obstet Gynaecol. 1983; 90: 671-5.

3. Malkasian GD, Symmonds RE, Dockerty MB. Malignant ovarian teratomas. Report of 31 cases. Obstet Gynecol. 1965; 25:810-4.

4. Hasleton PS, Kelehan P, Whittaker JS, Burslem RW, Turner L. Benign and malignant struma ovarii. Arch Pathol Lab Med. 1978; 102:180-4.

5. Andrews HR. Primary melanotic sarcoma of the ovary. Trans Obstet Soc (London). 1901; 43:228-31.

6. McNeilage LJ, Morgan J, Constable J, Jobling TW. Metastatic malignant melanoma arising in a mature ovarian cystic teratoma: A case report and literature review. Int J Gynecol Cancer. 2005; 15:1148-52.

7. Watanabe $Y$, Ueda $H$, Nakajima $H$, Minoura R, Hoshiai $H$, Noda $\mathrm{K}$. Amelanotic malignant melanoma arising in an ovarian cystic teratoma: A case report. Acta Cytol. 2001; 45:756-60.

8. Moehrle M, Fischbach H, Nuessle B, Rassner G. Primary malignant melanoma arising in a cystic necrotic ovarian teratoma. Eur J Obstet Gynecol Reprod Biol. 2001; 99:268-71.

9. O'Leary AJ, Tejura H. Malignant melanoma arising in a cystic teratoma of the ovary. J Obstet Gynaecol. 2005; 25:626-7.
10. Dhorigol VM, Malur PR, Natu. Primary malignant melanoma of the ovary a case report. Indian J Pathol Microbiol. 2005; 48:213-5.

11. Suneja A, Yadav P, Sharma A, Vaid NB, Singh B, Grover RK. Primary malignant melanoma cystic teratoma of ovary. Indian $\mathrm{J}$ Cancer. 2009; 46:340-2.

12. Lee SH, Lee KB, Shin JW, Chung DH, Park CY. An malignant melanoma without evidence of teratoma. J Obstet Gynaecol Res. 2010; 36:898-901.

13. Eisner RF, Nieberg RK, Berek JS. Synchronous primary neoplasms of the female reproductive tract. Gynecol Oncol. 1989; 33:335-9.

14. Kline RC, Wharton JT, Atkinson EN, Burke TW, Gershenson DM, Edwards CL. Endometrioid carcinoma of the ovary: Retrospective review of 145 cases. Gynecol Oncol. 1990; 39:33746.

15. Ukah CO, Ikpeze OC, Eleje GU, Eke AC. Adult granulosa cell tumor associated with endometrial carcinoma: A case report. J Med Case Reports. 2011; 5: 340.

16. Gök ND, Yildiz K, Corakçi A. Primary malignant melanoma of the ovary: Case report and review of the literature. Turk Patoloji Derg. 2011;27:169-72.

17. Cronje HS, Woodruff DW. Primary ovarian malignant melanoma arising in a cystic teratoma. Gynecol Oncol. 1981; 12:379-83.

18. McCluggage WG, Bissonnette JP, Young RH. Primary malignant melanoma of the ovary: A report of 9 definite or probable cases with emphasis on their morphologic diversity and mimicry of other primary and secondary ovarian neoplasms. Int J Gynecol Pathol. 2006; 25:321-9.

19. Scully RE. Tumors of the ovary and maldeveloped gonads. Washington, DC: Armed Forces Institute of Pathology; 1979. 255-63.

20. Davis GL. Malignant melanoma arising in mature ovarian cystic teratoma (dermoid cyst). Report of two cases and literature analysis. Int J Gynecol Pathol. 1996; 15:356-62.

21. Legha SS, Ring S, Eton O, Bedikian A, Buzaid AC, Plager C, Papadopoulos N. Development of a biochemotherapy regimen with concurrent administration of cisplatin, vinblastine, dacarbazine, interferon alfa, and interleukin-2 for patients with metastatic melanoma. J Clin Oncol.1998; 16:1752-9. 